DOI: 10.1515/ijek-2015-0009

\title{
STATISTICAL EVALUATION OF WORK PERFORMANCE FACTORS
}

\author{
Radim MAŇ́́K $K^{1}$ \\ Vysoká škola podnikání, a. s.
}

\begin{abstract}
The paper deals with work performance as a complex of different areas and views. The goal of the presented paper is to evaluate the dependences between various work performance aspects and various types of companies. It is based on an empirical research, which was realized with help of a written questionnaire, and statistical evaluation of gained data. The results should show to which extend the type of company influences approach to work performance and the correlations between individual aspects of performance.
\end{abstract}

\section{KEY WORDS}

Performance, indicator, measurement, correlation, SPSS

\section{INTRODUCTION}

The performance of human resources is a very fertile area of research, education and practical entrepreneurial activity. Measuring work performance is quite difficult task, but very important, too. It has to be accentuated that measurement of performance is necessary for effective personal management.

The problem is how to measure such complex entity as work performance and what aspects of performance should be considered.

This paper works with individual work performance factors and tries to find relations and connections among each other. Its goal is to describe the relations among individual aspects of performance.

To fulfill this goal, a statistical analysis of empirical data is performed. As main tool IBM SPSS Statistics program is used and the method of correlation analysis is carried out. The research was realized in 2012 and the statistical evaluation of gained data is presented in this paper.

The following text explains the research methodology and presents literature review and gained results.

$1 \quad$ Correspondence address: Radim, Maňák, Mgr. Ing. Ph.D.; 595228122; radim.manak@vsp.cz; Vysoká škola podnikání, Michálkovická 1810/181, 71000 Ostrava-Slezská Ostrava; www.vsp.cz 


\section{METHODOLOGICAL PROCEDURE}

For gaining primary data a questionnaire based research was realized. The goal of the research was to evaluate the level of monitoring quantitative and qualitative indicators in small and middle enterprises, to evaluate the importance of indicators for work performance measurement and to identify importance of work performance factors from the view of performance areas and time approach.

The basic set comprised limited liability companies with residence in Moravian-Silesian region that were listed in the database of European databank to the date of 20. 1. 2012. The size of the basic set was 6254 companies. The sample set was designed with help of random systematic selection and its size was 625 companies. The respondents were representatives of these companies, one for each. For the research purposes a questionnaire form was designed that consisted of specific parts. The first part concentrates at mapping and evaluating present situation in the companies, according to application of quantitative and qualitative indicators and complex approaches to performance measurement.

The next part deals with part areas of performance, which importance should be evaluated by the respondents. The choice of these part areas of performance relies on the theoretical background. As work performance areas were considered quantity of output, quality of output, relations at workplace, ethical approach, organizational culture, identification with organization and work safety.

The third part of questionnaire form pursues performance measurement from the time factor view. The fourth part is constituted of a question group, which are used to evaluate the importance of individual performance indicators. Identification questions are placed at the end of the form.

Distribution of the questionnaires, resp. of the link to the electronic form was realized through emails and electronic questionnaires were filled through Google Apps. The responds were gained from 196 companies with the respond rate of $31 \%$. One form was excluded for the purposes of next processing. The results are based on 195 questionnaires.

The structure of respondents was built as follows. All of them were limited liability companies with less than 250 employees, small and middle companies, where the strongest representation had companies with less than 10 employees (49\%), followed by companies with more than 10 but less than 50 employees (34\%) and companies with more than 50 but less than 250 employees (17\%). From the view of entrepreneurial sector, the strongest was tertiary sector (46\%), followed by secondary $(33 \%)$ and primarily sector $(21 \%)$. The questionnaire was determined to persons engaged in human resources management in the researched companies. The respondents taking part in the research consisted of company owners $(51 \%)$, managers on different levels of management $(37 \%)$ and human resources officers $(12 \%)$.

The evaluation of data was based on the statistical program IBM SPSS Statistics.

\section{THEORETICAL BACKGROUND}

It has to be accentuated that high level of attention is dedicated to measuring work performance (Bol, 2011; Feraru, Ciucescu, 2010; Gabel, Harker, Sanders, 2011; Janssens, Steyaert, 2009). 
For the purposes of research concept and its realization the following theoretical background was taken into consideration. From the literature research came out factors which characterize work performance.

For performance measurement it is necessary to work with its indicators, resp. criteria (Wagner, 2009), metrics (Učeň, 2008; Krajčík, 2011), value metrics (Truneček, 2004) and norms (standards) of performance (Koubek, 2004), which can be classified from different point of views (Šuleř, 2008; Walker et al. 2003; Sidor-Rzadkowska, 2004; Wagnerová, 2008). The classification of these indicators to quantitative and qualitative seems to be crucial for practical application.

It is important to discuss the components of work performance. Work performance is understood among others as output of work activity (Armstrong, 2007; Mayerová, 1997; Wagnerová, 2008).

Wagnerová (2008) specifies work performance as output of specific work activity reached in given time and under given conditions. The quantity and quality of output represent in this context quantitative and qualitative component of work activity result.

Relations at workplace are accentuated by Koubek (2004) and the ethical approach in the context of performance mention Vodák and Kucharčíková (2007), resp. EFQM Excellence Model (Nenadál, 2004).

The organizational culture as an important factor of competitiveness is to find by Vysekalová and Mikeš (2009) and Armstrong (2007). From the long-term point of view the key aspect of performance is the adaptability of culture. This adaptability is characterized by organizational learning, customer orientation and readiness to change (Lukášová, 2010).

Kasper and Mayrhofer (2005) and Towers Perrin (2008) mention identification with organization and its indicators. Competences as a part of performance in the sense of knowledge, abilities and skills are referred in Mayerová (1997), Mathis and Jackson (1988) and Koubek (2004). Pilařová (2008) defines competences as complex of knowledge, skills and attitudes, that enable individual to reach required performance.

Regarding to the strategic and complex approach to the human resources in the companies it is necessary to take in account the time aspect of performance (Proyecto Meritum, 2002; Covey, 2009; Covey; 2008, Hroník, 2008; Likierman, 2010; Hroník, 2006).

Covey (2009) distinguishes present production $\mathrm{P}$ and production capability to future PS. It is necessary to balance these two aspects because excessive result orientation leads to resources wear off. Hroník (2008) notes that not only present results but also the long-term performance are expected from managers.

The effect of work complexity is the need for complex approaches to performance measurement. One example is Balanced Scorecard method (Kaplan, Norton, 2005).

\section{RESULTS}

The respondents were asked to evaluate the importance of individual areas of work performance, whereby scale 1-5 was used. Value 1 interpreted the highest importance of the area and value 5 the lowest. Average values of evaluation for the performance areas were calculated with following formula (Řezanková, 2010): 
$\dot{x}=\frac{\sum_{j=1}^{k} X_{j} n_{j}}{n}$.

For each area of performance were calculated modal categories $x_{M o}$, median $\nsim$, ordinal variance dorvar, resp. discrete ordinal variance, and normalized ordinal variance norm. dorvar (Řezanková, 2010):

dorvar $=2 \sum_{i=1}^{K-1}\left(P_{i}\left(1-P_{i}\right)\right)$,

norm. dorvar $=\frac{2 \text { dorvar }}{K-1}$.

Identified values of ordinal variance are presented in the table 1.

Table 1 Ordinal variance of performance areas

\begin{tabular}{|l|l|r|r|r|}
\hline Performance area & $\begin{array}{l}\text { Modal } \\
\text { category } \\
x_{M o}\end{array}$ & Median $x$ & Dorvar & \multicolumn{1}{|l|}{$\begin{array}{l}\text { Norm. } \\
\text { dorvar }\end{array}$} \\
\hline Quantity of output & 3 & 3 & 1,1 & 0,55 \\
\hline Quality of output & 2 & 2 & 0,82 & 0,4 \\
\hline Relations at workplace & 4 & 4 & 1,34 & 0,67 \\
\hline Ethical approach & 3 & 3 & 1,3 & 0,65 \\
\hline Organizational culture & 4 & 4 & 1,31 & 0,66 \\
\hline $\begin{array}{l}\text { Identification with } \\
\text { organization }\end{array}$ & 2 & 3 & 1,34 & 0,67 \\
\hline Competences & 2 & 2 & 0,94 & 0,47 \\
\hline Work safety & 2 & 2 & 1,04 & 0,52 \\
\hline
\end{tabular}

Source: author

Ordinal variance dorvar takes values within the interval $\left\langle 0 ; \frac{K-1}{2}\right\rangle$, in this case $\langle 0,2\rangle$. Normalized ordinal variance norm. dorvar takes values within the interval from 0 to 1 . The highest values were indicated in the case of relations at workplace, identification with organization and ethical approach. At the other end the lowest values of ordinal variance were assigned to quality of output, competences and work safety.

For evaluation of next variability measures were identified values of variances for each area of performance:

$s_{x}^{2}=\frac{\sum_{j=1}^{k}\left(x_{j}-\dot{x}\right)^{2} n_{j}}{n}$.

As the next step were indicated values of standard deviation, according to formula (Řezanková, 2010):

$s_{x}=\sqrt{s_{x}^{2}}$.

Calculated values are presented in the table 2 .

Table 2 Performance areas - variance and standard deviation

\begin{tabular}{|l|r|r|r|}
\hline Performance area & $\begin{array}{l}\text { Average } \\
\text { evaluation } \dot{x}\end{array}$ & Variance $\mathbf{s}_{\mathbf{x}}{ }^{2}$ & $\begin{array}{l}\text { Standard } \\
\text { deviation } \mathbf{s}_{\mathbf{x}}\end{array}$ \\
\hline Quality of output & 1,84 & 0,6 & 0,77 \\
\hline Competences & 1,97 & 0,77 & 0,88 \\
\hline Work safety & 2,08 & 0,92 & 0,96 \\
\hline
\end{tabular}




\begin{tabular}{|l|r|r|r|}
\hline Quantity of output with & 2,44 & 0,99 & 0,99 \\
\hline $\begin{array}{l}\text { Identification } \\
\text { organization }\end{array}$ & 2,74 & 1,44 & 1,2 \\
\hline Ethical approach & 2,96 & 1,38 & 1,17 \\
\hline Organizational culture & 3,42 & 1,39 & 1,18 \\
\hline Relations at workplace & 3,43 & 1,46 & 1,2 \\
\hline
\end{tabular}

Source: author

As it can be seen in table 2, the highest values of variance are reached by ethical approach, organizational culture, identification with organization and relations at workplace. The lowest values were identified in the case of quality of output and competences.

In the context of the fact, that the values in the questionnaire come out of quantifiable scale, which is point determined, is the variance not the best statistical characteristic. It was therefore calculated relative coefficient of differentiation $\mathrm{P}_{\mathrm{d} \text { : }}$

$P_{d}=\frac{4 s_{x}^{2}}{R^{2}}(3.6)$

where $s_{x}^{2}$ stands for variance and $\mathrm{R}$ for variance range. This coefficient shows, to what extend the promoted scale extend was used by respondents in their answers. By the values of relation differentiation coefficient $P_{d}$ lower than 0,3 can be proclaimed, that the differentiation of evaluation is very low (Stáfková, Dufek, 2004).

The result values of relative coefficient of differentiation are shown in the table 3 .

Table 3 Relation differentiation coefficient of performance areas

\begin{tabular}{|l|r|}
\hline Performance area & $\begin{array}{l}\text { Relative coefficient } \\
\text { of differentiation } \mathbf{P}_{\mathbf{d}}\end{array}$ \\
\hline Quality of output & 0,15 \\
\hline Competences & 0,19 \\
\hline Work safety & 0,23 \\
\hline Quantity of output & 0,25 \\
\hline Identification with organization & 0,36 \\
\hline Ethical approach & 0,35 \\
\hline Organizational culture & 0,35 \\
\hline Relations at workplace & 0,37 \\
\hline
\end{tabular}

Source: author

The table 3 shows, that the differences in the evaluations of respondents are relatively low. The value of relation differentiation coefficient $P_{d}$ moves in the the range from 0,15 to 0,37 , whereby half of the areas take values lower than 0,3. These results represent low level of evaluation differentiation of respondents.

In the next part of questionnaire was examined the importance of performance areas from the time factor view. Respondents evaluated the importance of present and past performance and of perspective of future performance. The perspective of future performance was evaluated by the respondents as more important, it gained average value of 2,03. The present and past performance 
were evaluated by the average value of 2,68. Determined indicators of location and variability measures of the results are presented in following tables.

Table 4 Ordinal variances for time perspective of performance

\begin{tabular}{|l|r|r|r|r|}
\hline Time factor view & $\begin{array}{l}\text { Modal } \\
\text { category } x_{M o}\end{array}$ & Median $x$ & Dorvar & \multicolumn{1}{|l|}{$\begin{array}{l}\text { Norm. } \\
\text { dorvar }\end{array}$} \\
\hline $\begin{array}{l}\text { past and present } \\
\text { performance }\end{array}$ & 3 & 3 & 1,05 & 0,53 \\
\hline $\begin{array}{l}\text { perspective of } \\
\text { future performance }\end{array}$ & 2 & 2 & 0,99 & 0,49 \\
\hline
\end{tabular}

Source: author

Table 5 Relation differentiation coefficient for time perspective of performance

\begin{tabular}{|l|r|r|r|r|}
\hline Time factor view & $\begin{array}{l}\text { Average } \\
\text { evaluation } \\
\dot{x}\end{array}$ & $\begin{array}{l}\text { Variance } \\
\mathbf{S}_{\mathbf{x}}{ }^{2}\end{array}$ & $\begin{array}{l}\text { Standard } \\
\text { deviation } \mathbf{S}_{\mathbf{x}}\end{array}$ & $\begin{array}{l}\text { Relative } \\
\text { coefficient of } \\
\text { differentiation } \\
\mathbf{P}_{\mathbf{d}}\end{array}$ \\
\hline $\begin{array}{l}\text { past and present } \\
\text { performance }\end{array}$ & 2,68 & 0,92 & 0,96 & 0,23 \\
\hline $\begin{array}{l}\text { perspective of } \\
\text { future performance }\end{array}$ & 2,03 & 0,79 & 0,89 & 0,2 \\
\hline
\end{tabular}

Source: author

According to variability measures the established data show very low values, what can be proved primarily through low levels of ordinal variances dorvar and norm. dorvar and through relative coefficient of differentiation $\mathrm{P}_{\mathrm{d}}$. Differentiation of respondent evaluation was therefore very low.

It was proved that the future performance is more important than present performance, what correspondents with the strategic approach to human resources management. Perspective of future performance was evaluated with better values than performance in past and presence having no regards to number of employees in researched companies as is showed in the figure 1. 
Figure 1 Performance from time factor view according to number of employees

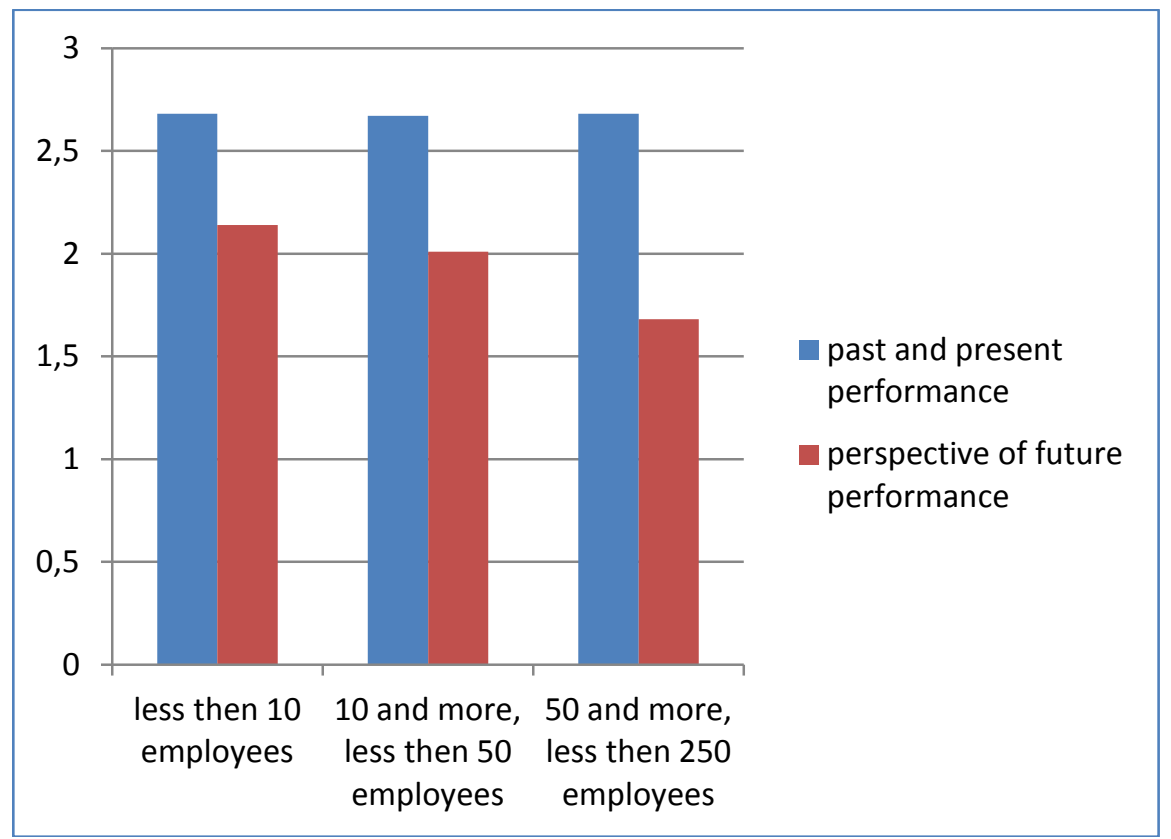

Source: author

In the next step of result evaluation an analysis of dependence of each variables was realized, which was processed with statistical programme IBM SPSS Statistics.

For evaluation of performance area importance according to entrepreneur sector Kruskal-Wallis test was used, whereby the zero hypothesis by this test assumes that all groups are characteristic with the same value of median of explained variable and vice versa the alternative hypothesis suggests

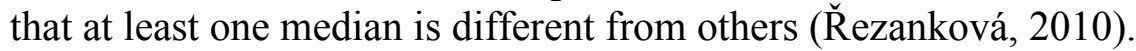

\section{Table 5 Kruskal-Wallis test for level of monitoring indicators and entrepreneur sector Test Statistics,}

\begin{tabular}{|l|r|r|}
\hline & $\begin{array}{c}\text { What attention gives your company to } \\
\text { monitoring and evaluation of qualitative } \\
\text { metrics of work performance? }\end{array}$ & $\begin{array}{c}\text { What attention gives your company to } \\
\text { monitoring and evaluation to quantitative } \\
\text { metrics of work performance? }\end{array}$ \\
\hline Chi-Square & 0,110 & 2 \\
df & 0,946 & 3,548 \\
Asymp. Sig. & 2 \\
\hline
\end{tabular}

a. Kruskal Wallis Test

b. Grouping Variable: companies due to sector

Source: author, IBM SPSS Statistics

As the presented values show, on the 5\% significance level it is possible to state that the zero hypothesis about sameness of medians in individual groups of companies according to entrepreneurs sectors is not rejected. It was proved that level of monitoring quantitative and qualitative indicators does not depend on entrepreneur sector. 
Table 6 Kruskal-Wallis test for performance areas and entrepreneur sector Test Statistics ${ }^{\mathbf{a}, \mathbf{b}}$

\begin{tabular}{|c|c|c|c|c|c|c|c|c|}
\hline & 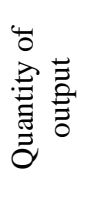 & 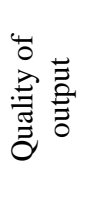 & 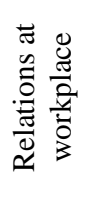 & 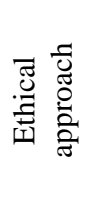 & 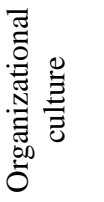 & 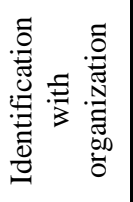 & 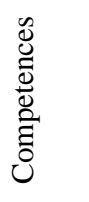 & 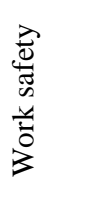 \\
\hline $\begin{array}{l}\text { Chi-Square } \\
\text { df } \\
\text { Asymp. Sig. }\end{array}$ & $\begin{array}{r}5,308 \\
2 \\
0,070 \\
\end{array}$ & $\begin{array}{r}8,625 \\
2 \\
0,013 \\
\end{array}$ & $\begin{array}{r}23,336 \\
2 \\
0,000 \\
\end{array}$ & $\begin{array}{r}10,326 \\
2 \\
0,006 \\
\end{array}$ & $\begin{array}{r}14,854 \\
2 \\
0,001\end{array}$ & $\begin{array}{r}6,493 \\
2 \\
0,039 \\
0,\end{array}$ & $\begin{array}{r}7,780 \\
2 \\
0,020 \\
\end{array}$ & $\begin{array}{r}4,780 \\
2 \\
0,092 \\
\end{array}$ \\
\hline
\end{tabular}

a. Kruskal Wallis Test

b. Grouping Variable: companies due sector

Source: author, IBM SPSS Statistics

By evaluating researched performance areas can be stated, that on 5\% significance level the zero hypothesis about sameness of medians can be rejected in the case of quality of output, relations at workplace, ethical approach, organizational culture, identification of organization and competences. Evaluation of these areas is statistically dependant on the variable entrepreneur sector. By importance of quantity of output and work safety was found no statistical relevant dependence on entrepreneur sector.

\section{Table 7 Kruskal-Wallis test for time factor and entrepreneur sector Test Statistics ${ }^{\mathrm{a}, \mathrm{b}}$}

\begin{tabular}{|l|r|r|}
\hline & \multicolumn{1}{|c|}{$\begin{array}{c}\text { Past and present } \\
\text { performance }\end{array}$} & $\begin{array}{c}\text { Perspective of future } \\
\text { performance }\end{array}$ \\
\hline Chi-Square & 5,825 & 7,585 \\
df & 2 & 2 \\
Asymp. Sig. & 0,054 & 0,023 \\
\hline
\end{tabular}

a. Kruskal Wallis Test

b. Grouping Variable: companies due sector

Source: author, IBM SPSS Statistics

In the case of performance areas according to the time factor view can be on 5\% significance level stated that the importance of past and present performance is not dependant on entrepreneur sector. In the case of future performance perspective was the independence on this significance level rejected.

For evaluation of correlation between company size and individual performance areas Spearman's coefficient of ordinal correlation was used, which evaluates order of values of variables by respondents. The coefficient takes values within interval $\langle-1 ; 1\rangle$. When same orders of both variables are found by respondents, coefficient acquires level 1, which means positive correlation, resp. direct dependence. If values of $\mathrm{X}$ variable in ascending order mean values of $\mathrm{Y}$ variable in descending order is the level of coefficient -1 , whereby it represents negative correlation, resp. indirect dependence. Zero level means linear independence (Řezanková, 2010).

With the help of Spearman's coefficient of order correlation was realised evaluation of dependence between level of monitoring of indicators and performance areas importance and size companies due to number of employees. Values of coefficient and minimal significance levels, at which zero hypothesis can be rejected, were gained with programme IBM SPSS Statistics and are shown in table 8 . 
Table 8 Spearman's coefficient of order correlation for performance areas and company size

\begin{tabular}{|c|c|c|}
\hline & \multicolumn{2}{|c|}{ Company size } \\
\hline & $\begin{array}{l}\text { Spearman's } \\
\text { coefficient }\end{array}$ & $\begin{array}{lr}\begin{array}{l}\text { Minimal level } \\
\text { significance } \\
\text { rejecting } \mathrm{H}_{0}\end{array} & \begin{array}{r}\text { of } \\
\text { for }\end{array}\end{array}$ \\
\hline $\begin{array}{l}\text { Monitoring of qualitative } \\
\text { indicators }\end{array}$ & $-0,034$ & 0,634 \\
\hline $\begin{array}{l}\text { Monitoring of quantitative } \\
\text { indicators }\end{array}$ & $-0,208$ & $0,004 *$ \\
\hline Quantity of output & 0,042 & 0,557 \\
\hline Quality of output & $-0,043$ & 0,550 \\
\hline Relations at workplace & $-0,222$ & $0,002^{*}$ \\
\hline Ethical approach & 0,125 & 0,083 \\
\hline Organizational culture & $-0,195$ & $0,006^{*}$ \\
\hline $\begin{array}{l}\text { Identification with } \\
\text { organization }\end{array}$ & $-0,267$ & $0,000^{*}$ \\
\hline Competences & $-0,284$ & $0,000^{*}$ \\
\hline Work safety & $-0,059$ & 0,417 \\
\hline Past and present performance & $-0,006$ & 0,939 \\
\hline $\begin{array}{l}\text { Perspective of future } \\
\text { performance }\end{array}$ & $-0,159$ & $0,027 *$ \\
\hline
\end{tabular}

Source: author, IBM SPSS Statistics

With asterisk those variables are marked in the table, for which it is possible at $5 \%$ significance level to reject the zero hypothesis about zero coefficient, which means, that marked variables are dependant at company size. In the case of monitoring of quantitative indicators, relations at workplace, organizational culture, identification with organization, competences and perspective of future performance is possible to state, that with growing number of employees in company these variables are evaluated as more important. These variables represent mostly soft, qualitative aspects of performance. The levels of coefficient is placed between $-0,284$ and $-0,159$, the strength of dependence is lower.

In the next step correlation between individual performance areas and time factor is evaluated.

Table 9 Spearman's coefficient of order correlation for performance areas and time factor of performance

\begin{tabular}{|l|r|r|r|r|}
\hline & \multicolumn{2}{|l|}{ Past and present performance } & \multicolumn{2}{|c|}{$\begin{array}{l}\text { Perspective of future } \\
\text { performance }\end{array}$} \\
\cline { 2 - 6 } & $\begin{array}{l}\text { Spearman's } \\
\text { coefficient }\end{array}$ & $\begin{array}{l}\text { Minimal } \\
\text { level of } \\
\text { significance } \\
\text { for rejecting } \\
\mathbf{H}_{\mathbf{0}}\end{array}$ & $\begin{array}{l}\text { Spearman's } \\
\text { coefficient }\end{array}$ & $\begin{array}{l}\text { Minimal } \\
\text { level of } \\
\text { significance } \\
\text { for rejecting } \\
\mathbf{H}_{\mathbf{0}}\end{array}$ \\
\hline $\begin{array}{l}\text { Quantity of } \\
\text { output }\end{array}$ & 0,253 & $0,000^{*}$ & $-0,038$ & 0,599 \\
\hline Quality of output & 0,063 & 0,384 & 0,228 & $0,001^{*}$ \\
\hline $\begin{array}{l}\text { Relations at } \\
\text { workplace }\end{array}$ & $-0,031$ & 0,671 & 0,389 & $0,000^{*}$ \\
\hline
\end{tabular}




\begin{tabular}{|l|r|r|r|r|}
\hline Ethical approach & 0,063 & 0,389 & 0,111 & 0,125 \\
\hline $\begin{array}{l}\text { Organizational } \\
\text { culture }\end{array}$ & $-0,082$ & 0,255 & 0,198 & $0,006^{*}$ \\
\hline $\begin{array}{l}\text { Identification } \\
\text { with organization }\end{array}$ & $-0,046$ & 0,522 & 0,375 & $0,000^{*}$ \\
\hline Competences & $-0,083$ & 0,252 & 0,374 & $0,000^{*}$ \\
\hline Work safety & 0,118 & 0,102 & 0,074 & 0,307 \\
\hline
\end{tabular}

Source: author, IBM SPSS Statistics

The asterisk shows, that on 5\% significance level the hypothesis about zero coefficient was rejected. As the presented values show, on this significance level the dependence at importance of past and present performance was proved only in case of quantity of output. The level of Spearman's coefficient is in this case 0,253 , it means positive correlation and lower dependence strength.

In the case of future performance perspective statistical dependence was discovered in more cases. It can be stated, that at 5\% significance level importance of future performance perspective is dependant with quality of output, relation at workplace, organizational culture, identification with organization and competences. In all cases positive correlation was detected, whereby Spearman's coefficient takes vales within 0,198 and 0,389 . The strongest dependence is by relation at workplace, identification with organization and competences. In these cases respondents with higher importance of future performance perspective evaluated as more important these performance aspects, too. They all represent qualitative characteristics of performance.

In the appendix is shown correlation matrix, where Spearman's coefficient values between performance areas can be found. Positive correlation of higher strength was detected between quantity of output and quality of output $(0,431)$, relation at workplace and organizational culture $(0,620)$, relations at workplace and identification with organization $(0,635)$, relation at workplace and competences $(0,399)$, ethical approach and organizational culture $(0,436)$, identification with organization and competences $(0,473)$. Especially significant is dependence between relations at workplace at one side and organizational culture and identification with organization at the other side.

As it comes out from Spearman's coefficient values for individual performance indicators due to company size, it was proved in a lot of cases direct correlation between company size and importance of qualitative indicators, the strongest correlation was in case of work satisfaction, work attitudes, competence level, organizational culture level and team work ability. With growing company size grows then importance of these indicators, which have qualitative character.

\section{DISCUSSION}

The gained data and its statistical analysis yielded interesting expert results. Author of this paper is aware of the fact that different circumstances could provide different results.

For example Pheng and Chuan (2006) obtained data of 124 respondents for their research which examined impact of variables on work performance of project managers. They determined team relationship as "the most important variable affecting the performance of project manager". Job security was at the other end of the scales. These results are in contrast with performed research where relations at workplace were evaluated as the least important. 
A research by Horáková (2005) presents yet another point of view. 1075 respondents evaluated satisfaction in various aspects of work. Among the high ranked factors belonged again relations at workplace, at the other end landed such hard factors as remuneration.

\section{CONCLUSIONS}

As the theoretical background shows, components of work performance can be understood as quantity and quality of output, relations at workplace, ethical approach, organizational culture, identification with organization, competences and work safety. Above all, the time aspect of performance has to be taken into consideration.

The presented results have shown interesting relations between individual aspects of work performance and dependences of these aspects according to type of companies.

The data showed that the level of evaluation of differentiation was relatively low.

It was proved that perspective of future performance is more important than past and present performance in all types of companies.

Various entrepreneur sectors influence the understanding of importance of individual performance areas. Most of these areas importance level depend on entrepreneur sector; the only exceptions are quantity of output and work safety. Divergences were found by time factor view. Importance of past and present performance doesn't depend on sector, but importance of future performance is dependant.

Influence was indicated in case of company size, too. With growing number of employees in company such performance areas are evaluated as more important as relations at workplace, organizational culture, identification with organization, competences and perspective of future performance. It can be stated that the larger companies take more in account the importance of the qualitative aspect of performance. Company size influences importance of individual performance indicators. Larger companies understand as more important such indicators as work satisfaction, competence level or team work ability.

It was proved that the importance of past and present performance correlates with the importance of quantity of output. Companies with more accents on quantifiable work outputs concentrate more on past and present concept of performance. It is interesting that companies laying more accents on future performance take more in account the qualitative and less quantifiable performance areas as relations at workplace, identification with organization and competences.

It can be assumed that the companies understand the importance of qualitative areas of performance and of the perspective of future performance. Furthermore this understanding is stronger by larger companies. 


\section{REFERENCES}

Armstrong, Michael. (2007) Řízení lidských zdrojů. 10 $0^{\text {th }}$ ed. Praha: Grada Publishing. 802 p. ISBN 978-80-247-1407-3.

Bol, Jasmijn, C. (2011) The Determinants and Performance Effects of Managers' Performance Evaluation Biases. Accounting Review [online]. vol. 86, no. 5 [cit. 2015-6-1]. ISSN 0001-4826. Available from: http://aaajournals.org/doi/abs/10.2308/accr-10099

Covey, Stephen R. (2008) 8. návyk. Od efektivnosti k výjimečnosti. Praha: Management Press. ISBN 978-80-7261-138-6.

Covey, Stephen R. (2009) 7 návyků skutečně efektivních lidí. Praha: Management Press. ISBN 978-80-7261-156-0.

Feraru, Andreea and Ciucescu, Nicoleta. (2010) Theoretical and methodological aspects of the professional performances evaluation. Annals of Faculty of Economics [online]. vol. 2, issue 2 [cit. 2015-6-1]. Avalaible at: http://econpapers.repec.org/article/orajournl/v_3a1_3ay_3a2010_3ai_3a2_3ap_3a939-944.htm

Gabel, Lisa, Harker, Kate and Sander, Ethan S. (2011) Leadership Development: What's Evaluation Got to Do With It? T+D [online]. vol. 65, no. 3 [cit. 2015-6-2]. ISSN 1535-7440. Available from: http://www.astd.org/TD/Archives/2011/TOC/1103MarTOC.htm

Horáková, Naděžda. (2005) Spokojenost s jednotlivými aspekty práce [online]. [cit. 2015-6-2]. Available from: http://cvvm.soc.cas.cz/media/com_form2content/documents/c1/a3258/f3/100530s_eu51115.pdf

Hroník, František. (2006) Hodnocení pracovníků. $1^{\text {st }}$ ed. Praha: Grada Publishing. 128 p. ISBN 80247-1458-2.

Hroník, František. (2008) Manažerská integrita. $1^{\text {st }}$ ed. Brno: Motiv Press. 152 p. ISBN 978-80904133-0-6.

Janssens, Maddy and Steyart, Chris. HRM and Performance: A Plea for Reflexivity in HRM Studies. Journal of Management Studies [online]. 2009, vol. 46, no. 1, p. 143 - 155 [cit. 2015-63]. ISSN 1467-6486. Available from: http://onlinelibrary.wiley.com/doi/10.1111/j.14676486.2008.00812.x/full

Kaplan, Robert S. and Norton, David P. (2005) Balanced Scorecard. Strategický systém měření výkonnosti podniku. 4. vyd. Praha: Management press. ISBN 80-7261-124-0.

Kasper, Helmut and Mayrhofer, Wolfgang. (2005) Personální management - Rízení - Organizace. $3^{\text {rd }}$ ed. Praha: Linde. 592 p. ISBN 80-86131-57-2.

Kobek, Josef. (2004) Ř́zení pracovního výkonu. $1^{\text {st }}$ ed. Praha: Management Press. ISBN 80-7261116-X.

Krajčík, Vladimír. (2011) Model kvality na soukromé vysoké škole. Karlovarská právní revue. vol. 7, no. 2. ISSN 1801-2193.

Likierman, Andrew. (2010) Pět léček při měření výkonnosti. Moderní řízení. no. 9. ISSN 00268720.

Lukášová, Růžena. (2010) Organizační kultura a její změna. 1. vyd. Praha: Grada Publishing. ISBN 978-80-247-2951-0.

Mathis, Robert L. and Jackson, John H. (1988) Personel/Human Resource Management. $5^{\text {th }}$ ed. St. Paul, New York, Los Angeles, San Francisco: West Publishing Company. ISBN 0-314-62317-5. 
Mayerová, Marie. (1997) Stres, motivace a výkonnost. $1^{\text {st }}$ ed. Praha: Grada Publishing. 136 p. ISBN 80-7169-425-8.

Nenadál, Jaroslav. (2004) Měření v systémech managementu jakosti. $2^{\text {nd }}$ ed. Praha: Management Press. 335 p. ISBN 80-7261-110-0.

Pheng, Low Sui and Chuan, Quek Tai. (2006) [cit. 2015-06-02]. Environmental factors and work performance of project managers in the construction industry. International Journal of Project Management [online]. vol. 24, No. 1, 24-37. ISSN 0263-7863. Avalaible from: http://www.sciencedirect.com/science/article/pii/S0263786305000633

Pilařová, Irena. (2008) Jak efektivně hodnotit zaměstnance a zvyšovat jejich výkonnost. Praha: Grada Publishing. 128 s. ISBN 978-80-247-2042-5.

Proyecto Meritum [online]. (2002) [cit. 2010-02-25]. Available from: www.uam.es

Řezanková, Hana. (2010) Analýza dat z dotazníkových šetření. $2^{\text {nd }}$ ed. Praha: Professional Publishing. ISBN 978-80-7431-019-5.

Sidor-Rządkowska, Małgorzata. (2004) Zarządzanie personelem w malej firmie. Kraków: Oficyna Ekonomiczna. 191 p. ISBN 83-89-35549-3.

Stáfková, Jana and Dufek, Jaroslav. (2004) Marketingový výzkum. Brno: Mendelova zemědělská a lesnická univerzita v Brně. ISBN 80-7175-795-2.

Šuleř, Oldřich. (2008) 5 rolí manažera a jak je profesionálně zvládnout. $1^{\text {st }}$ ed. Brno: Computer Press. ISBN 978-80-251-2316-4.

Towes Perrin. (2008) Global Workforce Study 2007 - 2008 [online]. [cit. 2009-09-15]. Available from: www.towersperrin.com

Truneček, Jan. (2004) Znalostní podnik ve znalostní společnosti. $2^{\text {nd }}$ ed. Praha: Professional Publishing. ISBN 80-86419-67-3.

Učeň, Pavel. (2008) Zvyšování výkonnosti firmy na bázi potenciálu zlepšení. $1^{\text {st }}$ ed. Praha: Grada Publishing. ISBN 978-80-247-2472-0.

Vodák, Josef and Kucharčíková, Alžbeta. (2007) Efektivní vzdělávání zaměstnanců. $1^{\text {st }}$ ed. Praha: Grada Publishing. ISBN 978-80-247-1904-7.

Vysekalová, Jitka and Mikeš, Jiř́i. (2009) Image a firemní identita. $1^{\text {st }}$ ed. Praha: Grada Publishing. 192 p. ISBN 978-80-247-2790-5.

Wagner, Jaroslav. (2009) Měření výkonnosti. $1^{\text {st }}$ ed. Praha: Grada Publishing. 256 p. ISBN 978-80247-2924-4.

Wagnerová, Irena. (2008) Hodnocení a řízení výkonnosti. $1^{\text {st }}$ ed. Praha: Grada Publishing. ISBN 978-80-247-2361-7.

Walker, Alfred J. et al. (2003) Moderní personální management: Nejnovější trendy a technologie. $1^{\text {st }}$ ed. Praha: Grada Publishing. 253 p. ISBN 80-247-0449-8. 
Appendix 1 Correlation matrix of performance areas

Correlations

\begin{tabular}{|c|c|c|c|c|c|c|c|c|c|c|}
\hline & & & $\begin{array}{l}\text { Quantity } \\
\text { of output }\end{array}$ & $\begin{array}{c}\text { Quality } \\
\text { of output }\end{array}$ & $\begin{array}{l}\text { Relat. at } \\
\text { work. }\end{array}$ & $\begin{array}{l}\text { Ethical } \\
\text { appr. }\end{array}$ & $\begin{array}{l}\text { Organ. } \\
\text { culture }\end{array}$ & $\begin{array}{l}\text { Ident. } \\
\text { With } \\
\text { org. }\end{array}$ & Compet. & $\begin{array}{l}\text { Work } \\
\text { safety }\end{array}$ \\
\hline \multirow{13}{*}{$\begin{array}{l}\text { Spearman's } \\
\text { rho }\end{array}$} & $\begin{array}{l}\text { Quantity of } \\
\text { output }\end{array}$ & $\begin{array}{l}\text { Correlation } \\
\text { Coefficient } \\
\text { Sig. (2-tailed) } \\
\mathrm{N}\end{array}$ & $\begin{array}{r}1,000 \\
. \\
194\end{array}$ & $\begin{array}{r}, 431^{* * *} \\
, 000 \\
194 \\
\end{array}$ & $\begin{array}{r}, 012 \\
, 868 \\
194 \\
\end{array}$ & $\begin{array}{r}, 163^{*} \\
, 024 \\
192 \\
\end{array}$ & $\begin{array}{r}-, 183^{*} \\
, 011 \\
194 \\
\end{array}$ & $\begin{array}{r}, 005 \\
, 943 \\
193 \\
\end{array}$ & $\begin{array}{r}, 153^{*} \\
, 033 \\
194 \\
\end{array}$ & $\begin{array}{r}, 348^{* *} \\
, 000 \\
193 \\
\end{array}$ \\
\hline & $\begin{array}{l}\text { Quality of } \\
\text { output }\end{array}$ & $\begin{array}{l}\text { Correlation } \\
\text { Coefficient } \\
\text { Sig. (2-tailed) } \\
\mathrm{N}\end{array}$ & $\begin{array}{r}, 431^{* * *} \\
, 000 \\
194 \\
\end{array}$ & $\begin{array}{r}1,000 \\
. \\
195\end{array}$ & $\begin{array}{r}, 310^{* *} \\
, 000 \\
195 \\
\end{array}$ & $\begin{array}{r}, 171^{*} \\
, 017 \\
193 \\
\end{array}$ & $\begin{array}{r}, 128 \\
, 074 \\
195 \\
\end{array}$ & $\begin{array}{r}, 332^{* * *} \\
, 000 \\
194 \\
\end{array}$ & $\begin{array}{r}, 373^{* *} \\
, 000 \\
195 \\
\end{array}$ & $\begin{array}{r}, 232^{* * *} \\
, 001 \\
194 \\
\end{array}$ \\
\hline & $\begin{array}{l}\text { Relations at } \\
\text { workplace }\end{array}$ & $\begin{array}{l}\text { Correlation } \\
\text { Coefficient } \\
\text { Sig. (2-tailed) } \\
\mathrm{N}\end{array}$ & $\begin{array}{r}, 012 \\
, 868 \\
194 \\
\end{array}$ & $\begin{array}{r}, 310^{* *} \\
, 000 \\
195 \\
\end{array}$ & $\begin{array}{r}1,000 \\
. \\
195 \\
\end{array}$ & $\begin{array}{r}, 347^{* *} \\
, 000 \\
193 \\
\end{array}$ & $\begin{array}{r}, 620^{* *} \\
, 000 \\
195 \\
\end{array}$ & $\begin{array}{r}, 635^{* *} \\
, 000 \\
194 \\
\end{array}$ & $\begin{array}{r}, 399^{* * *} \\
, 000 \\
195 \\
\end{array}$ & $\begin{array}{r}, 002 \\
, 975 \\
194 \\
\end{array}$ \\
\hline & $\begin{array}{l}\text { Ethical } \\
\text { approach }\end{array}$ & $\begin{array}{l}\text { Correlation } \\
\text { Coefficient } \\
\text { Sig. (2-tailed) } \\
\mathrm{N}\end{array}$ & $\begin{array}{r}, 163^{*} \\
, 024 \\
192 \\
\end{array}$ & $\begin{array}{r}, 171^{*} \\
, 017 \\
193 \\
\end{array}$ & $\begin{array}{r}, 347^{* *} \\
, 000 \\
193 \\
\end{array}$ & 193 & $\begin{array}{r}, 436{ }^{* *} \\
, 000 \\
193 \\
\end{array}$ & $\begin{array}{r}, 244^{* * *} \\
, 001 \\
192 \\
\end{array}$ & $\begin{array}{r}, 055 \\
, 449 \\
193 \\
\end{array}$ & $\begin{array}{r}-, 042 \\
, 559 \\
192 \\
\end{array}$ \\
\hline & Organ. culture & $\begin{array}{l}\text { Correlation } \\
\text { Coefficient } \\
\text { Sig. (2-tailed) } \\
\text { N }\end{array}$ & $\begin{array}{r}-, 183^{*} \\
, 011 \\
194\end{array}$ & $\begin{array}{r}, 128 \\
, 074 \\
195\end{array}$ & $\begin{array}{r}, 620^{* *} \\
, 000 \\
195\end{array}$ & $\begin{array}{r}, 436^{* * *} \\
, 000 \\
193\end{array}$ & $\begin{array}{r}1,000 \\
. \\
195\end{array}$ & $\begin{array}{r}, 388^{* * *} \\
, 000 \\
194\end{array}$ & $\begin{array}{r}, 155^{*} \\
, 030 \\
195\end{array}$ & $\begin{array}{r}-, 160^{*} \\
026 \\
194\end{array}$ \\
\hline & \multirow[b]{2}{*}{$\begin{array}{l}\text { Ident. With } \\
\text { org. }\end{array}$} & $\begin{array}{l}\text { Correlation } \\
\text { Coefficient }\end{array}$ & ,005, &, $332^{* *}$ &, $635^{* *}$ &, $244^{* *}$ &, $388^{* *}$ & 1,000 &, $473^{* *}$ & ,118 \\
\hline & & $\begin{array}{l}\text { Sig. (2-tailed) } \\
\mathrm{N}\end{array}$ & $\begin{array}{r}, 943 \\
193 \\
\end{array}$ & $\begin{array}{r}, 000 \\
194 \\
\end{array}$ & $\begin{array}{r}, 000 \\
194 \\
\end{array}$ & $\begin{array}{r}, 001 \\
192 \\
\end{array}$ & $\begin{array}{r}, 000 \\
194 \\
\end{array}$ & 194 & $\begin{array}{r}, 000 \\
194 \\
\end{array}$ & $\begin{array}{r}104 \\
193 \\
\end{array}$ \\
\hline & \multirow{3}{*}{ Competences } & $\begin{array}{l}\text { Correlation } \\
\text { Coefficient }\end{array}$ &, $153^{*}$ &, $373^{* *}$ &, $399^{* *}$ &, 055 &, $155^{*}$ &, $473^{* *}$ & 1,000 &, $241^{\text {*** }}$ \\
\hline & & Sig. (2-tailed) & ,033 &, 000 & ,000 & ,449 &, 030 &, 000 & & ,001 \\
\hline & & $\mathrm{N}$ & 194 & 195 & 195 & 193 & 195 & 194 & 195 & 194 \\
\hline & \multirow{3}{*}{ Work safety } & $\begin{array}{l}\text { Correlation } \\
\text { Coefficient }\end{array}$ &, $348^{* * *}$ &, $232^{* *}$ & ,002 &,- 042 &,$- 160^{*}$ &, 118 &, $241^{* *}$ & 1,000 \\
\hline & & Sig. (2-tailed) & ,000 &, 001 & ,975 &, 559 & ,026 &, 104 &, 001 & \\
\hline & & $\mathrm{N}$ & 193 & 194 & 194 & 192 & 194 & 193 & 194 & 194 \\
\hline
\end{tabular}

**. Correlation is significant at the 0.01 level (2-tailed).

*. Correlation is significant at the 0.05 level (2-tailed).

Source: author, IBM SPSS Statistics 